Prepared for the National Aeronautics and Space Administration

\title{
Geologic Map of Olympus Mons Caldera, Mars
}

By Peter J. Mouginis-Mark

Pamphlet to accompany

Scientific Investigations Map 3470

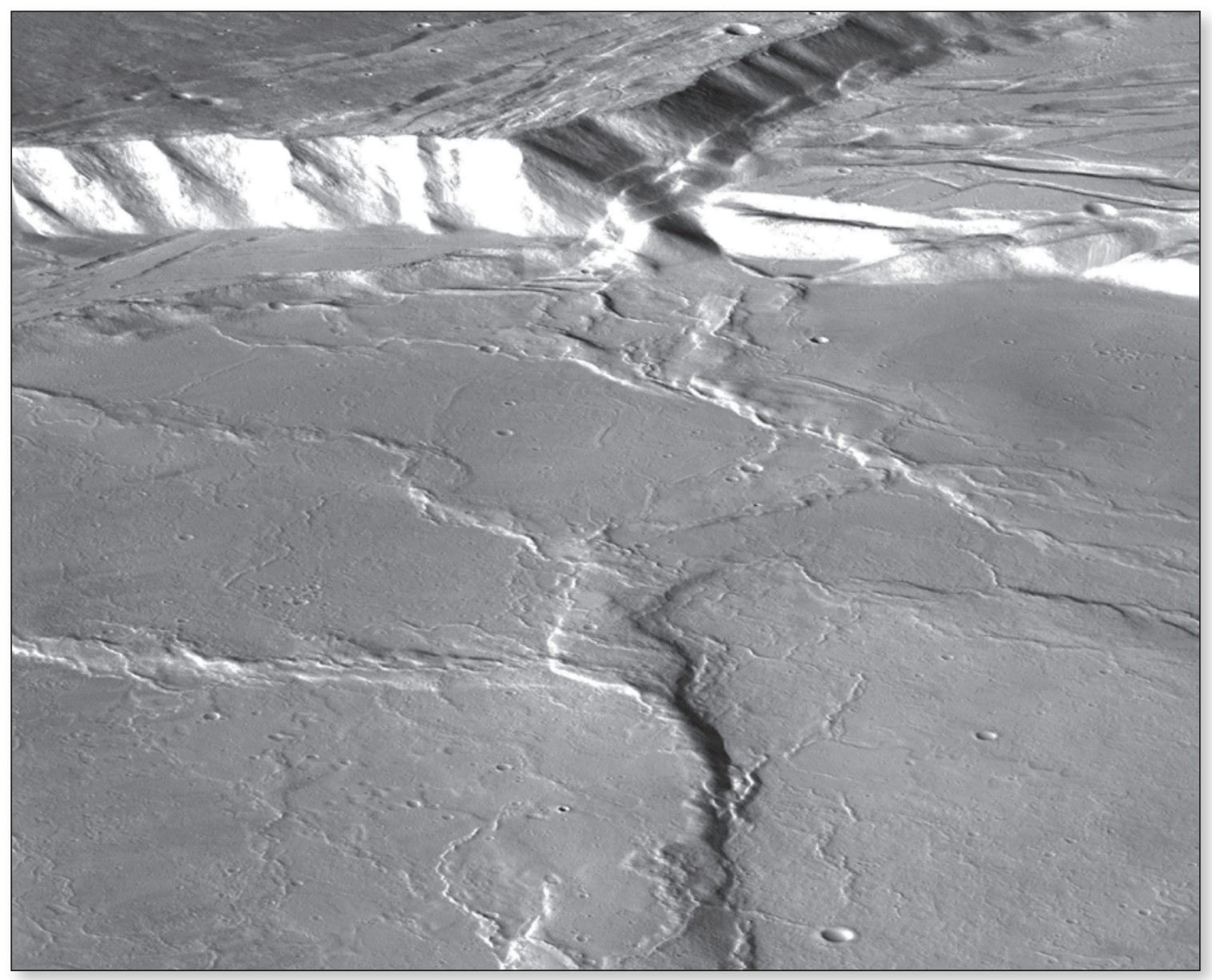

U.S. Department of the Interior

U.S. Geological Survey 


\section{U.S. Geological Survey, Reston, Virginia: 2021}

For more information on the USGS — the Federal source for science about the Earth, its natural and living resources, natural hazards, and the environment-visit https://www.usgs.gov or call 1-888-ASK-USGS.

For an overview of USGS information products, including maps, imagery, and publications, visit https://store.usgs.gov.

Any use of trade, firm, or product names is for descriptive purposes only and does not imply endorsement by the U.S. Government.

Although this information product, for the most part, is in the public domain, it also may contain copyrighted materials as noted in the text. Permission to reproduce copyrighted items must be secured from the copyright owner.

Suggested citation:

Mouginis-Mark, P.J., 2021, Geologic map of Olympus Mons caldera, Mars: U.S. Geological Survey Scientific Investigations Map 3470, 6 p., 1 sheet, scale 1:200,000, https://doi.org/10.3133/sim3470.

ISSN 2329-1311 (print)

ISSN 2329-132X (online)

Cover. Summit caldera of Olympus Mons volcano, Mars, displays a complex history of volcanism and tectonism. This computer-generated oblique view looks northwest across the floor of Hermes Patera. Height of wall is $\sim 1,150 \mathrm{~m}$. Width of image in foreground is $\sim 8.7 \mathrm{~km}$. Width along caldera wall is $\sim 20 \mathrm{~km}$. Base image is Mars Reconnaissance Orbiter Context Camera (CTX) frame P07_003621_1980; topographic data were derived from CTX images P07_003621_1980 and P10_005032_1980. 


\section{Contents}

Introduction

Base Map and Data

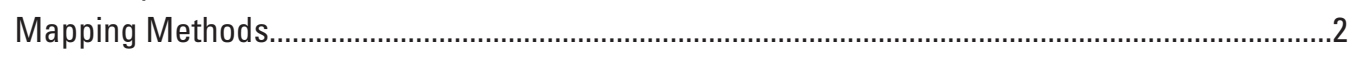

Age Determinations

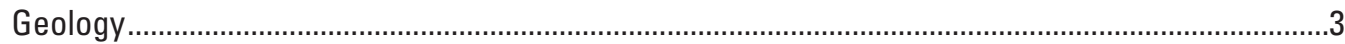

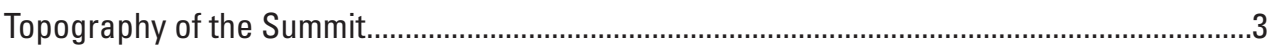

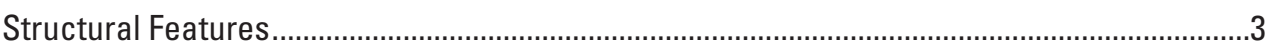

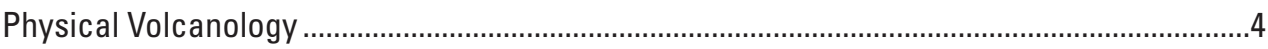

Pangboche Crater ................................................................................................................

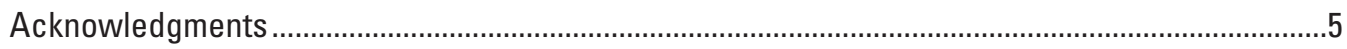

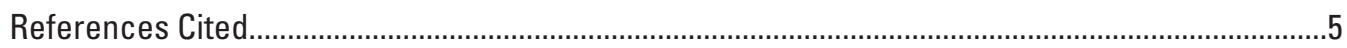

\section{Figures}

1. Topography of summit of Olympus Mons map area derived from Mars Orbiter Laser Altimeter (MOLA) data, showing names of paterae within Olympus Mons caldera and highest point on the volcano. map sheet

2. Image of west caldera rim of Olympus Mons caldera, showing that the lobate lava flows (unit $\mathrm{Aos}_{2}$ ) and lava channels on the rim do not extend onto the floor of either Hera or Hermes Paterae, which implies that the paterae floors were resurfaced after their formation map sheet

3. Graph comparing topographic profiles derived from gridded Mars Orbiter Laser Altimeter (MOLA) topography along seven lava flows on the south and east flanks of the caldera map sheet

4. Images of parts of Zeus Patera show differences in the distribution of blocks and mantle materials within the individual graben. map sheet

5. Images showing details of the chronology of caldera collapse that are evident in the west caldera wall map sheet

6. Image showing detailed view of floor of Hermes Patera (unit $\mathrm{Aoc}_{3}$ ), showing materials that are interpreted to be deformed surfaces of cooled lava lakes.. map sheet

7. Image showing boundary between Dionysus (unit $\mathrm{Aoc}_{3}$ ) and Apollo (unit $\mathrm{Aoc}_{5}$ ) Paterae, where a candidate volcanic vent is visible map sheet

\section{Table}

1. Comparison of different chronologies of Olympus Mons summit deposits by various researchers. 


\title{
Geologic Map of Olympus Mons Caldera, Mars
}

\author{
By Peter J. Mouginis-Mark
}

\section{Introduction}

The Martian volcano, Olympus Mons (lat $18.65^{\circ} \mathrm{N}$., long $226.20^{\circ} \mathrm{E}$.), is the highest and most prominent shield volcano in the solar system, is $\sim 600$ kilometers $(\mathrm{km})$ in diameter, and rises $\sim 22$ $\mathrm{km}$ above the northwest edge of the informally named "Tharsis rise" (Smith and others, 2001; Plescia, 2004). The volcano summit displays a nested series of pits (paterae), which collectively form the summit caldera. Details of the geology and topography of Olympus Mons provide key insights into the relative timing of caldera-collapse episodes, as well as the post-emplacement deformation of the summit. A series of previous geologic maps (Carr, 1975; Morris and Dwornik, 1978; Scott and others, 1981; Morris and Tanaka, 1994) at scales varying from 1:5,000,000 to $1: 1,000,000$ included the summit of Olympus Mons but were constructed from Mariner 9 and Viking Orbiter images with variable resolution generally poorer than 150 meters/pixel (m/pixel). As a result of the images used, individual lava flows near the caldera were not identified. A 1:1,000,000-scale geologic map of the entire volcano by Garry and others (2015) employed higher resolution images $(25-100 \mathrm{~m} /$ pixel) and illustrated the general distribution of younger lava flows at the summit but similarly provided insufficient detail to correlate individual features with the summit topography.

Utilizing topographic data derived from stereo Viking Orbiter images (Wu and others, 1984), Mouginis-Mark and Robinson (1992) first drew attention to the topography of the caldera rim and observed that the highest point lies to the south of the rim (fig. 1). With the advent of topography derived from Mars Orbiter Laser Altimeter (MOLA) (Smith and others, 2001) and images from the Mars Reconnaissance Orbiter Context Camera (CTX) (Malin and others, 2007) and the High Resolution Imaging Science Experiment (HiRISE) (McEwen and others, 2007) at a resolution of $\sim 6$ $\mathrm{m} /$ pixel and 25 centimeter/pixel (cm/pixel), respectively, MouginisMark and Wilson (2019) demonstrated that many of the lava flows at the summit appear to have flowed uphill and no longer conform to the present-day topography. The interrelations between these lava flows and the present-day topography, as well as the complex post-emplacement tilting of the floors of the paterae, provide the motivation for this new geologic/topographic map. The map is intended to provide details of the structural features (for example, graben and wrinkle ridges) within the caldera and lava flows on the flanks and place them in the context of the present-day setting to show how much the topography has changed since their formation.
Within the 80- x 65-km caldera are six nested paterae that indicate the preserved summit has undergone multiple collapse episodes, flooding by lava, and subsequent deformation. Zeus Patera is the largest structure, originally measuring $\sim 60 \times 65 \mathrm{~km}$ before subsequent collapse events removed the southern segment. Striking topographic variations $(1.3-1.5 \mathrm{~km})$ exist between the low point in the middle of the patera and the perimeter of the floor. Hera Patera is a crescent fragment of caldera floor containing numerous faults concentric to the side of the floor. A single radial ridge, perpendicular to the faults, is observed on the floor of Hera Patera. The eastward trace of the rim indicates that Hera Patera formed after Zeus Patera. Hermes and Dionysus Paterae form two connected depressions to the west of Zeus Patera. Prominent ridges observed on the floor of Hermes Patera are predominantly radial to the center, and two of these ridges cross into Zeus Patera. Numerous faults adjacent to the north wall of Apollo Patera are observed on the south side of Hermes Patera and the west side of Dionysus Patera. Clusters of irregular craters occur on the southern floor of Dionysus Patera. Athena Patera forms a near-circular 20- x 22-km pit at the northeastern extent of the caldera. Several ridges occur on the floor. Apollo Patera is $12 \times 16 \mathrm{~km}$ and lies at the southwest end of the caldera. A pair of topographic rises ( $\sim 200$ and $\sim 80 \mathrm{~m}$ high) are observed along the northeast side. Numerous clusters of irregular craters are scattered across the surface, and a lobe of material extends onto the southern part of the floor from the wall. An irregular pit $(\sim 2.5 \mathrm{~km}$ in diameter) is observed at the east margin of the floor.

Greeley and Spudis (1981) interpreted numerous tectonic features on the caldera floor to have been formed by compression (wrinkle ridges) and extension (graben). These features are believed to have been associated with subsidence associated with magmachamber deformation (Zuber and Mouginis-Mark, 1992) and more regional tilting of the summit (Mouginis-Mark and Wilson, 2019).

This map includes Pangboche crater (10.4 km in diameter), located close to the south caldera rim of Olympus Mons. The distal ejecta blanket from Karzok crater, which lies northeast of the map area, is also mapped.

\section{Base Map and Data}

As the archetype of a Martian shield volcano, the summit of Olympus Mons has been extensively imaged by numerous spacecraft. The base image for the map (at $25 \mathrm{~m} / \mathrm{pixel}$ ) is

${ }^{1}$ University of Hawaii 
a single image (image number H6220_0000_ND3) from the High Resolution Stereo Camera (HRSC) onboard the Mars Express spacecraft (Neukum and others, 2004), which is used to preserve uniform lighting geometry across the entire map area. Elevation data obtained from the gridded version of measurements from the MOLA instrument are available from NASA's Planetary Data System (https://ode.rsl.wustl.edu/mars/), have a pixel resolution of $463 \mathrm{~m} /$ pixel, and have a total elevation uncertainty of at least $\pm 3 \mathrm{~m}$ (Neumann and others, 2001). A subset of topographic data derived from CTX images covers parts of the caldera floor at a spatial resolution of $24 \mathrm{~m} /$ pixel and shows a vertical accuracy of approximately 3-5 m (Mouginis-Mark, 2018). As described in the Mapping Methods section, many key features are not discernable in the base map; instead, HiRISE and CTX images were used to recognize features across the map area and were transferred at scale to the base map.

The HRSC base image used for the map includes numerous albedo features. Dark patches on the caldera floor, as well as bright patches on the summit to the south of the caldera rim, result from mobile fine materials that were redistributed despite the very low atmospheric pressure (Bridges and others, 2010). These fine materials represent surficial materials visible on the base, but they are not mapped or described in this publication. Thermal infrared data collected by the Thermal Emission Imaging System (THEMIS) were used to document the physical characteristics of the floor of Pangboche crater.

\section{Mapping Methods}

The U.S. Geological Survey (USGS) assembled a geographic information system (GIS) project that contains the HRSC mosaic at a spatial resolution of $25 \mathrm{~m} / \mathrm{pixel}$ and the MOLA/ HRSC digital terrain model (DTM). Points, lines, and polygons were digitized using GIS at a scale of 1:50,000. Geologic map symbols were derived from Federal Geographic Data Committee Digital Cartographic Standards for Geologic Map Symbolization (Federal Geographic Data Committee, 2006) and were adapted where necessary to convey the geologic information unique to this area. Contact line work was cleaned (dangles removed) and used to build unit polygons. Contours on the map are displayed at $100-\mathrm{m}$ intervals, and every $500-\mathrm{m}$ contour is bold. Individual point elevations were extracted from the gridded DTM. Geologic unit names (where applicable) are adopted from those defined by Morris and Tanaka (1994) and Garry and others (2015). Where a pair of graben walls face each other at a distance of $<400 \mathrm{~m}$, the graben symbol on the map is shown as a single trace.

Some attributes of the volcano can only be recognized at a resolution that is higher than the $25 \mathrm{~m} /$ pixel HRSC base image, for example, the lava flows on the flanks of the volcano and the relation between ejecta from Pangboche crater and the adjacent lava flows. These features were mapped using CTX images at full resolution ( $\sim 6 \mathrm{~m} /$ pixel) and then transferred to the HRSC base at map scale.

No vents can be identified for any of the individually mapped lava flows; therefore, the upslope extent of each flow approximates the point of origin of the flow. Uncertainties also exist in the identification of flow boundaries where multiple units abut each other, such as outcrops of unit $\mathrm{Aos}_{2}$ in the southeastern portion of the map.
As conventional for terrestrial shield volcanoes, the individual Olympus Mons paterae have been given formal names by the International Astronomical Union (fig. 1). These paterae are named after the Greek Olympian gods who were believed to inhabit Mount Olympus, the highest mountain in Greece, and purported to be the seat of the gods by Homer, the legendary Greek author of The Iliad \& The Odyssey. Pangboche crater is named after a Nepalese base camp for mountain climbers en route to the summit of Mount Everest.

\section{Age Determinations}

By analogy with terrestrial calderas (Mouginis-Mark and others, 2007), the oldest materials within the map area may well be the lower layers exposed in the wall materials (unit Aow). Because they are only viewed in vertical section, none of these layers are assigned ages, although it seems probable that the oldest material in the map area lies at the base of the deepest part of Apollo Patera.

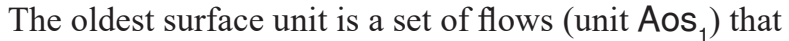
appears weathered to remove fine-scale morphology and form the majority of the summit area (Mouginis-Mark, 2018). Lack of prominent morphologic features indicates that these flows are significantly older than a few hundred lava flows (unit $\mathrm{Aos}_{2}$ ) that have mappable lobate margins (unit Aos ${ }_{2}$ ) that radiate in almost all azimuths from the summit caldera (fig. 2). Many unit $\mathrm{Aos}_{2}$ flows are cut by the caldera rim, predate the formation of the caldera, and represent remnants from a time period when no caldera existed (Mouginis-Mark, 1981, 2018). Some flows have central channels. Northeast of the map area, unit Aos $_{2}$ flows partially bury the ejecta blanket of the impact crater Karzok (located east of the map area). Ejecta from Pangboche crater south of Olympus Mons caldera postdates the emplacement of unit Aos $_{2}$ flows.

Ages of the six paterae have previously been determined using crater counts from HRSC images (Neukum and others, 2004) and from CTX images (Robbins and others, 2011); however, these counts disagree with the stratigraphic ages of the paterae (Mouginis-Mark, 2018). Neukum and others (2004) interpreted Hera Patera to be the youngest collapse feature at $\sim 100 \mathrm{Ma}$, followed by Zeus Patera $(\sim 140 \mathrm{Ma})$, Hermes/Dionysus Paterae ( 170 Ma), Apollo Patera ( 200 $\mathrm{Ma})$, and Athena Patera ( $200 \mathrm{Ma})$ as the oldest. Robbins and others (2011) also identified Hera Patera ( 140 Ma) as the youngest, followed by Hermes Patera ( 330 Ma), Zeus Patera ( 340 Ma), Apollo Patera ( 360 Ma), Athena Patera ( $\sim 380 \mathrm{Ma})$ and, the oldest, Dionysus Patera ( 420 Ma). From the crosscutting relations preserved within the caldera, the sequence from youngest to oldest appears to be Apollo Patera, Hermes/Dionysus Paterae, Hera Patera, and Zeus Patera, with Athena Patera forming sometime after Zeus Patera (MouginisMark, 1981). Possible explanations for the disparities in crater counts and stratigraphy may be the occurrence of clusters of secondary craters from Pangboche crater on the floor of Apollo and Dionysus Paterae and the possibility that parts of the floors have been resurfaced by more recent lava flows after the large-scale collapse. Resurfacing undoubtedly took place, 
because the floors possess relatively smooth surfaces with no large collapse blocks visible. Even at HiRISE resolution, no morphologic evidence for individual lava flows (for example, flow lobes) is evident on the caldera floor. Table 1 presents these three contrasting interpretations of the chronology of paterae formation.

Pangboche crater must be relatively youthful, in part because ejecta from this crater partially covers the floor of Apollo Patera (Mouginis-Mark, 1981, 2018) and also because of the preservation of 20 -m-diameter blocks on the crater rim (Mouginis-Mark, 2015). Another area of secondary craters is mapped in the northeastern part of the map area. These craters originate from Karzok crater (15.6 km diameter), which lies just east of the map area. No secondary craters from Karzok crater can be found on the floor of Athena Patera, and the ejecta is partially buried by some of the differentiated lava flows (unit $\mathrm{Aos}_{2}$ ), placing the formation of Karzok crater as intermediate in age between the undifferentiated lava flows (unit Aos $_{1}$ ) and the eruption of the differentiated flows (unit Aos ${ }_{2}$ ).

\section{Geology}

\section{Topography of the Summit}

The highest point of the volcano $(21,290 \mathrm{~m})$ is not the caldera rim (Mouginis-Mark and Robinson, 1992). Rather, the caldera formed $\sim 11 \mathrm{~km}$ to the north of this high point, with the highest part of the rim $\sim 200 \mathrm{~m}$ lower than the peak. The crest of the caldera rim varies in elevation from 21,080 $\mathrm{m}$ at the southwest rim of Apollo Patera (unit $\mathrm{Aoc}_{5}$ ) to 19,380 m on the northeast rim of Athena Patera (unit $\mathrm{Aoc}_{4}$ ). Typical heights of the caldera wall are 1.3-1.5 km for the rim of Zeus Patera (unit $\mathrm{Aoc}_{1}$ ) and $2.9 \mathrm{~km}$ for Apollo Patera. Hera Patera (unit Aoc ) is $\sim 360 \mathrm{~m}$ above the floor of Hermes Patera (unit $\mathrm{Aoc}_{3}$ ) and $\sim 1,370 \mathrm{~m}$ below the caldera rim. The maximum height of the wall between Zeus and Dionysus Paterae (unit $\mathrm{Aoc}_{3}$ ) is $885 \mathrm{~m}$. Athena Patera lies $\sim 1,800$ m below the caldera rim and $\sim 1,090$ $\mathrm{m}$ below the adjacent portions of Zeus Patera.

Floors of the six paterae are highly variable in elevation (Mouginis-Mark and Wilson, 2019). The floor of Zeus Patera is highest $(\sim 19,500 \mathrm{~m})$ close to the east wall and lowest $(\sim 18,000$ $\mathrm{m})$ in the center of the patera. As noted by Zuber and MouginisMark (1992), the middle of Zeus Patera is lower by $\sim 1,200 \mathrm{~m}$ than the floor adjacent to the wall. Hermes Patera has a similar distribution of elevations, with the west floor higher than the east area close to the center of the caldera complex. The elevation of Hermes Patera drops $\sim 160 \mathrm{~m}$ across a prominent 2- $\mathrm{x} 14-\mathrm{km}$ concentric wrinkle ridge.

Topographic profiles that parallel the lava flow directions of unit $\mathrm{Aos}_{2}$ on the south and east rims of the caldera (fig. 3) show that some of the flows now increase in elevation by $\sim 200-350$ $\mathrm{m}$ before descending the flanks (Mouginis-Mark and Wilson, 2019). At 1:200,000 scale, the summit caldera of Olympus Mons exhibits excellent examples of volcanic and tectonic processes associated with recent (Late Amazonian) shield volcanism on Mars (Mouginis-Mark and Robinson, 1992).
Table 1. Comparison of different chronologies of Olympus Mons summit deposits by various researchers.

\begin{tabular}{llll}
\hline Amazonian & \multicolumn{1}{c}{$\begin{array}{c}\text { Neukum and } \\
\text { others, 2004 }\end{array}$} & $\begin{array}{l}\text { Robbins and } \\
\text { others, 2011 }\end{array}$ & $\begin{array}{c}\text { Mouginis-Mark, } \\
\mathbf{2 0 1 8}\end{array}$ \\
\hline Youngest & Hera & Hera & Apollo/Athena \\
& Zeus & Hermes & Hermes/Dionysus \\
& Hermes/Dionysus & Zeus & Hera \\
& Apollo/Athena & Apollo & Zeus \\
& & Athena & \\
Oldest & & Dionysus & \\
\hline
\end{tabular}

\section{Structural Features}

The oldest portion of the Olympus Mons caldera floor (Zeus Patera) is characterized by numerous circumferential graben close to the caldera wall and ridges close to the patera center; the transition between these two features is $\sim 16 \mathrm{~km}$ from center. A pair of broad ridge arches cross the boundary betweeen Zeus Patera and Hermes Patera. Zuber and Mouginis-Mark (1992) used this distribution to model the possible depth and geometry of the magma chamber at the time that deformation took place. Their model placed the top of the chamber within the volcanic edifice at a depth of $\sim 16 \mathrm{~km}$ below the floor of Zeus Patera. Downward sagging of the central portion of the caldera floor of Zeus Patera is, therefore, comparable to that of Nindiri Crater in Masaya Volcano, Nicaragua (Mouginis-Mark and others, 2007). A north-south disparity in elevation of the floor may be due to post-collapse inflation of the south caldera rim (Mouginis-Mark and Wilson, 2019). Large ridge arches extend across Hermes and Dionysus Paterae, as well as the lower parts of Zeus Patera. By analogy with active terrestrial lava lakes (Lopes and others, 2004), it seems likely that these ridge arches are not of tectonic origin and, thus, are different from wrinkle ridges observed on the Moon, Mercury, or elsewhere on Mars (Watters, 1988; Crane and Klimczak, 2019). Our preferred interpretation is that they formed as lava squeezed up through cracks on the surface crust of a convecting lava pond and subsequently became frozen into the surface of the pond as the lake cooled.

Graben are restricted to Zeus Patera and, to a lesser extent, Hera Patera. Concentric graben on the floor of Zeus Patera are typically $\sim 500 \mathrm{~m}$ wide, as long as $23 \mathrm{~km}$, and 80-100 m deep (maximum depths $\sim 180 \mathrm{~m}$ ). No layering is observed within the walls of these graben, suggesting that the flows that produced the current floor of Zeus Patera may be at least $200 \mathrm{~m}$ thick. Marked differences in the occurrence of boulders within the graben can be identified (fig. 4) far from the caldera center. Blocks on the graben floors are much more numerous compared to those closer to the caldera center, which suggest that graben close to the caldera wall may have been active more recently than graben closer to the caldera center and have been less modified by subsequent erosion and burial by dust.

Hera Patera formed on the west side of the caldera following the formation of Zeus Patera (fig. 5). Local deformation resulted in the formation of wrinkle ridges followed by 
circumferential graben. The floor of Hera Patera most likely comprises a series of thin ( 10-15 m) lava flows, because multiple layers can be identified in the patera floor where it is cut by Hermes Patera. Around the perimeter of all the paterae, bright wall material (unit Aow) can be observed. Near the top of the unit, this wall material includes a series of layers and is interpreted to be a sequence of lava flows or solidified lava lakes associated with the pre-collapse phase of volcanic activity, and these layers predate the surface expression of the undifferentiated summit flows (unit Aos $)$ ). Bright albedo material that has accumulated at the base of the walls is either fragmented rock or scree material produced by weathering of the walls.

Striking examples of ridge arches exist on the floor of Hermes and Zeus Paterae (fig. 6). These ridge arches may be $\sim 2 \mathrm{~km}$ wide and rise $\sim 160 \mathrm{~m}$ above adjacent parts of the caldera floor (Mouginis-Mark, 2018), show multiple examples of smaller ridge elements superimposed upon larger ridge arches, and may cross the boundaries between adjacent paterae. Although determining the sequence of events that formed these ridge arches is not possible, the smaller ridge elements formed prior to the larger ridge arches because there is no obvious evidence for topographic control of these smaller ridge elements. This chronology of ridge formation is numbered at several locations on figure 6 .

Deformation was evidently the greatest on the south and east flanks of the volcano (Mouginis-Mark and Wilson, 2019). Narrow $(<100 \mathrm{~m})$ ridge elements as long as $\sim 5 \mathrm{~km}$ are broadly concentric to the caldera rim and cut the unit Aos $_{2}$ flows. These raised-ridge elements, along with the normal faults on the southeast flank, may have formed in response to the same deformation events that formed the ridge arches of the caldera floor within Zeus and Hermes Paterae.

We assume that, similar to lava lakes on Earth, the floor of each patera was originally created as a horizontal surface. This may not have been true in all cases, as post-collapse eruptions may have been preferentially located in one part of the caldera floor, creating uneven topography on the floor. However, the lack of individual lava-flow lobes, or a concentration of preserved structural features in one part of the patera, supports the idea of broader resurfacing by the eruption of lava flows that covered the entire patera. Even at HiRISE resolution, layers observed in the wall between Hera and Hermes Paterae (fig. 5B) cannot be followed for a sufficient distance to determine if they represent wide flows (or lava lakes) that filled the caldera and then spilled over the caldera rim or if they are the exposed segments of narrow flows comparable in dimension to the ones observed on the upper flanks.

\section{Physical Volcanology}

Particularly on the west and east caldera rims, some truncated flows can be observed (fig. 2). No vents for these flows can be found, indicating that they have been destroyed by subsequent collapse events that formed the paterae. Lava flows in this locality are predominantly narrow $(\sim 1 \mathrm{~km})$, and some possess central channels. Sets of irregularly shaped collapse features with no raised rims can be observed on the northeast and northwest rims and are interpreted to be a series of sky-lights over lava tubes.
In contrast to the summit areas of other large Martian volcanoes, the shallow magma reservoir of Olympus Mons (there may have been several reservoirs, as is the case at terrestrial shield volcanoes such as Kîlauea, Island of Hawai 'i, Hawaii; Ryan and others, 1981) is interpreted to have decreased in size over time (Mouginis-Mark, 1981). Episodic activity (Wilson and others, 2001) and horizontal migration took place over distances of $\sim 30 \mathrm{~km}$ beneath Zeus Patera to form both Athena and Apollo Paterae. Paterae of intermediate age (Hera, Hermes, and Dionysus) indicate that the direction of magma-reservoir migration was towards the south and west. No evidence for earlier collapse events outside of the current perimeter of the caldera can be identified, although numerous fractures on the northeast rim of Athena Patera may indicate a failed larger area of collapse. Volcanism within the caldera was confined to each individual patera, with no preserved evidence for flows spilling from one patera to another. In addition, no evidence can be found for late-stage intracaldera volcanism of the type observed in the caldera of Arsia Mons volcano (Richardson and others, 2017).

A pair of irregular depressions (LL in fig. 6) with low raised rims can be identified on the floor of Hermes Patera. These are interpreted to be relic lava lakes and are subtle topographic lows surrounded by concentric boundaries that could have formed by the lake draining in a manner analogous to the lava lake in Kîlauea Iki in 1959 on the Island of Hawai'i (Eaton and others, 1987). An irregular pit ( $2.5 \mathrm{~km}$ in diameter) on the east margin of Apollo Patera may be a small vent (fig. 7). A pair of topographic benches $\sim 80 \mathrm{~m}$ (fig. 7) and $\sim 200 \mathrm{~m}$ high exists on the northeast side of Apollo Patera (fig. 7) and possibly represents a highstand of lava within this patera. No evidence is preserved on the floor of any patera of individual lava flows or larger solidified lava lakes, although resurfacing by lava must have taken place within each patera because no collapse blocks that are associated with caldera formation (for example, at La Cumbre Volcano, Fernandina Island, Galapagos, Ecuador; Simkin and Howard 1970) can be identified. Secondary craters from Pangboche crater can be found on the floors of Dionysus and Apollo Paterae.

\section{Pangboche Crater}

The 10.4-km-diameter Pangboche crater (lat $17.2^{\circ} \mathrm{N}$., long $226.7^{\circ}$ E.) lies within the area mapped (fig. 1), has an impact origin, and lies close to the summit at an elevation of $20.9 \mathrm{~km}$ above the Mars datum, which is the elevation above a mean planetary radius of 3,382.9 km (Smith and others, 2001). Ballistically emplaced ejecta from Pangboche crater is scattered across the floors of Apollo and Dionysus Paterae, suggesting the formation of Pangboche crater is the youngest major event in the map area. Given a scale height of $\sim 11 \mathrm{~km}$ for the atmosphere, this large fresh crater most likely formed at an atmospheric pressure $<1$ millibar (mbar) in essentially volatile-free young lava flows (Mouginis-Mark, 2015) and provides unique insights into the cratering process on Mars without the influence of an atmosphere or target volatiles. Young Martian impact craters typically illustrate numerous features that indicate the 
presence of volatiles (either water ice or liquid water) within the target at the time of their formation (Carr and others, 1977; Mouginis-Mark and Boyce, 2012). The floor material (unit $\mathrm{Ap}_{1}$ ) at Pangboche crater is hummocky, with blocks as much as 150 $\mathrm{m}$ in diameter embedded in the surface. Smooth surfaces show banding in the downslope direction. The wall and rim materials (unit $\mathrm{Ap}_{2}$ ) show layers in the upper portions and have spur and gully morphology. Lower inner slopes have bland morphology and appear to be partially buried by material that has a swirl texture. They are interpreted to represent a section through target rocks, believed to be a sequence of lava flows from the summit (Mouginis-Mark, 2015). The exterior part of the unit is hummocky, with ejecta blocks as much as $\sim 70 \mathrm{~m}$ in diameter observed on the rim crest. The floor $\left(A p_{1}\right)$ and the wall units $\left(A p_{2}\right)$ of Pangboche crater are bright on nighttime data from the Thermal Emission Imaging System (THEMIS) infrared (IR) camera, which has a spatial resolution of $100 \mathrm{~m} /$ pixel (Christensen and others, 2004). THEMIS IR data indicate exposed bedrock in the walls and on the floor materials. The inner wall is interpreted to be a sequence of lava flows from the summit comparable to unit Aos $_{1}$.

\section{References Cited}

Bridges, N.T., Banks, M.E., Beyer, R.A., Chuang, F.C., Noe Dobrea, E.Z., Herkenhoff, K.E., Kesztheli, L.P., Fishbaugh, K.E., McEwen, A.S., Michaels, T.I., Thomsson, B.J., and Wray, J.J., 2010, Aeolian bedforms, yardangs, and indurated surfaces in the Tharsis Montes as seen by the HiRISE Camera-Evidence for dust aggregates: Icarus, v. 205, p. 165-182.

Carr, M.H, 1975, Geologic map of the Tharsis quadrangle of Mars: U.S. Geological Survey Miscellaneous Investigations Series Map I-893, scale 1:5,000,000, http://pubs.er.usgs.gov/ publication/i893.

Carr, M.H., Crumpler, L., Cutts, J., Greeley, R., Guest, J., and Masursky, H., 1977, Martian impact craters and emplacement of ejecta by surface flow: Journal of Geophysical Research, v. 82, p. 4055-4065.

Christensen, P.R., Jakosky, B.M., Kieffer, H.H., Malin, M.C., McSween, H.Y., Nealson, K., Mehall, G.L., Silverman, S.H., Ferry, S., Caplinger, M., and Ravine, M., 2004, The Thermal Emission Imaging System (THEMIS) for the Mars 2001 Odyssey Mission: Space Science Reviews, v. 110, p. 85-130.

Crane, K.T., and Klimczak, C., 2019, Tectonic patterns of shortening landforms in Mercury's northern smooth plains: Icarus, v. 317 , p. 66-80.

Eaton, J.P., Richter, D.H., and Krivoy, H.L., 1987, Cycling of magma between the summit reservoir and Kilauea Iki lava lake during the 1959 eruption of Kilauea volcano, in Decker, R.W., Wright, T.L., and Stauffer, P.H., eds., Volcanism in Hawaii: U.S. Geological Survey Professional Paper 1350, p. 1307-1334.

Federal Geographic Data Committee [prepared for the Federal Geographic Data Committee by the U.S. Geological Survey], 2006, FGDC Digital cartographic standard for geologic map
Materials ejected from Pangboche crater extend as a coherent unit to $\sim 1$ crater radius from the crater rim, but discontinuous ejecta that extend to $\sim 7$ crater radii is superposed on the floor of Dionysus and Apollo Paterae. Parts of unit $\mathrm{Ap}_{2}$ and the discontinuous ejecta blanket display a herringbone pattern characteristic of fresh secondary craters on the Moon (Oberbeck and Morrison, 1973) and, no doubt, formed in a similar manner in association with the Pangboche impact event.

\section{Acknowledgments}

I thank James Skinner, Trent Hare, Corey Fortezzo, and Marc Hunter at the U.S. Geological Survey (USGS), Flagstaff, Arizona, for significant assistance in the preparation of the digital version of this map. Thanks also to Lazlo Kestay and Alex Huff (USGS) for their technical reviews. Harold Garbell (University of Hawaii) is thanked for generating the digital elevation model used to create the pamphlet illustration. This research was conducted under funding from the National Aeronautics and Space Administration (NASA), Planetary Geology and Geophysics Program, grant NNG05GH51G.

symbolization: Reston, Va., Federal Geographic Data Committee Document Number FGDC-STD-013-2006, 290 p., 2 plates.

Garry, W.B., Williams, D.A., Bleacher, J.E., and Dapremont, A.M., 2015, Geologic mapping of Olympus Mons and the Tharsis Montes, Mars: 46th Lunar and Planetary Science Conference, abstract 1008.

Greeley, R., and Spudis, P.D., 1981, Volcanism on Mars: Reviews of Geophysics and Space Physics, v. 19, p. 13-41.

Lopes, R.M.C., Kamp, L.W., Smythe, W.D., Mouginis-Mark, P., Kargel, J., Radebaugh, J., Turtle, E.P., Perry, J., Williams, D., Carlson, R.W., and Dout, S., 2004, Lava lakes on Io? Observations of Io's volcanic activity from Galileo NIMS during the 2001 fly-bys: Icarus, v. 169, no. 1, p. 140-174.

Malin, M.C., Bell III, J.F., Cantor, B.A., Caplinger, M.A., Calvin, W.M., Clancy, R.T., Edgett, K.S., Edwards, L., Haberle, R.M., James, P.B., Lee, S.W., Ravine, M.A., Thomas, P.C., and Wolff, M.J., 2007, Context Camera investigation on board the Mars Reconnaissance Orbiter: Journal of Geophysical Research, v. 112, no. E5, https://doi.org/10.1029/2006JE002808.

McEwen, A.S., Eliason, E.M., Bergstrom, J.W., Bridges, N.T., Hansen, C.J., Delamere, W.A., Grant, J.A., Gulick, V.C., Herkenhoff, K.E., Keszthelyi, L., Kirk, R.L., Mellon, M.T., Squyres, S.W., Thomas, N., and Weitz, C.M., 2007, Mars Reconnaissance Orbiter's High Resolution Imaging Science Experiment (HiRISE): Journal of Geophysical Research, v. 112, no. E5, https://doi.org/10.1029/2005JE002605.

Morris, E.C., and Dwornik, S.E., 1978, Geologic map of the Amazonis quadrangle of Mars: U.S. Geological Survey Miscellaneous Investigations Map I-1049, scale 1:5,000,000.

Morris, E.C., and Tanaka, K.L., 1994, Geologic maps of the Olympus Mons region of Mars: U.S. Geological Survey Miscellaneous Investigations Map I-2327, scales 1:2,000,000 and 1:1,000,00. 
Mouginis-Mark, P.J., 1981, Late-stage summit activity of Martian shield volcanoes: Proceedings of Lunar and Planetary Science Conference, 12th, p. 1431-1447.

Mouginis-Mark, P.J., 2015, Cratering on Mars with almost no atmosphere or volatiles - Pangboche crater: Meteoritics and Planetary Science, v. 50, p. 51-62.

Mouginis-Mark, P.J., 2018, Olympus Mons volcano, Mars-A photogeologic review and new insights: Geochemistry, v. 78, no. 4, p. 397-431.

Mouginis-Mark, P.J., and Boyce, J.M., 2012, Tooting craterGeology and geomorphology of the archetype large, fresh, impact crater on Mars: Chemie der Erde Geochemistry, v. 72, p. 1-23.

Mouginis-Mark, P.J., Harris A.J.L., and Rowland, S.K., 2007, Terrestrial analogs to the calderas of the Tharsis volcanoes of Mars, in Chapman, M., ed., The geology of Mars-Evidence from Earth-based analogs: England, Cambridge University Press, p. 71-94.

Mouginis-Mark, P.J., and Robinson, M.J., 1992, Evolution of the Olympus Mons caldera, Mars: Bulletin of Volcanology, v. 54, p. 347-360.

Mouginis-Mark, P.J., and Wilson, L., 2019, Late-stage intrusive activity at Olympus Mons, Mars - Summit inflation and giant dike formation: Icarus, v. 319, p. 459-469.

Neukum, G., Jaumann, R., Hoffmann, H., Hauber, E., Head, J.W., Basilevsky, A.T., Ivanov, B.A., Werner, S.C., van Gasselt, S., Murray, J.B., McCord, T., and The HRSC Co-Investigator Team, 2004, Recent and episodic and glacial activity on Mars revealed by the High Resolution Stereo Camera: Nature, v. 432, p. 971-979.

Neumann, G.A., Smith, D.E., and Zuber, M.T., 2001, Crossover analysis of Mars Orbiter Laser Altimeter data: Journal of Geophysical Research, v. 106, no. 10, p. 23,753-23,768.

Oberbeck, V.R., and Morrison, R.H., 1973, On the formation of the lunar herringbone pattern: Proceedings of the Fourth Lunar Science Conference, v. 1, p. 107-123.

Plescia, J.B., 2004, Morphometric properties of Martian volcanoes: Journal of Geophysical Research, v. 109, E03003, https://doi.org/10.1029/2002JE002031.
Richardson, J.A., Wilson, J.A., Connor, C.B., Bleacher, J.E., and Kiyosugi, K., 2017, Recurrence rate and magma effusion rate for the latest volcanism on Arsia Mons, Mars: Earth and Planetary Science Letters, v. 458, p. 170-178.

Robbins, S.J., Di Achille, G., and Hynek, B.M., 2011, The volcanic history of Mars-High-resolution crater-based studies of the calderas of 20 volcanoes: Icarus, v. 211, p. 1179-1203.

Ryan, M.P., Koyanagi, R.Y., and Fiske, R.S., 1981, Modeling the three-dimensional structure of macroscopic magma transport systems - Application to Kilauea volcano, Hawaii: Journal of Geophysical Research, v. 86, no. B8, p. 7111-7129.

Scott, D.H., Schaber, G.G., Horstmann, K.C., Dial, A.L., and Tanaka, K.L., 1981, Map showing lava flows in the northwest part of the Tharsis quadrangle of Mars: U.S. Geological Survey Miscellaneous Investigation Series Map I-1266 (MC-9 NW), scale 1:2,000,000.

Simkin, T., and Howard, K.A., 1970, Caldera collapse in the Galapagos Islands, 1968: Science, v. 169, p. 429-437.

Smith, D.E., Zuber, M.T., Frey, H.V., Garvin, J.B., Head, J.W., Muhleman, D.O., Pettengill, G.H., Phillips, R.J., Solomon, S.C., Zwally, H.J., Banerdt, W.B., Duxbury, T.C., Golombek, M.P., Lemoine, F.G., Neumann, G.A., Rowlands, D.D., Aharonson, O., Ford, P.G., Ivanov, A.B., Johnson, C.L., McGovern, P.J., Abshire, J.B., Afzal, R.S., and Sun, X., 2001, Mars Orbiter Laser Altimeter-Experiment summary after the first year of global mapping of Mars: Journal of Geophysical Research, v. 106, p. 23,689-23,722.

Watters, T.R., 1988, Wrinkle ridge assemblages on the terrestrial planets: Journal of Geophysical Research, v. 93, no. B9, p. 10,236-10,254.

Wilson, L., Scott, E.D., and Head, J.W., 2001, Evidence for episodicity in the magma supply to the large Tharsis volcanoes: Journal of Geophysical Research, v. 106, p. 1423-1433.

Wu, S.S.C., Garcia, P.A., Jordan, R., Schafer, F.J., and Skiff, B.A., 1984, Topography of the shield volcano, Olympus Mons, Mars: Nature, v. 309, p. 432-435.

Zuber, M.T., and Mouginis-Mark, P.J., 1992, Caldera subsidence and magma chamber depth of the Olympus Mons volcano, Mars: Journal of Geophysical Research v. 97, p. 18,295-18,307. 